\title{
HUBUNGAN ANTARA KETAHANAN FISIK MENTAL SPIRITUAL DAN KEMAMPUAN MENGELOLA STRES SERTA TINGKAT KEPERCAYAAN DIRI DENGAN MOTIVASI KERJA
}

\author{
FX. Suwarto \\ Fakultas Ekonomi Universitas Atmas Jaya Yogyakarta \\ Email:fx.suwarto@yahoo.com
}

\begin{abstract}
This research problems: Do there are korelation by parsial and by together among/between physical resilience bounce spiritual (X1) ability and to manage stress (X2) and also mount trust of x'self (X3) of with work Motivation (Y). This Research aim to to be able to know by parsial and by variabel dependence $(Y)$ with independence variable (X). Result of research indicate that by parsial and by together there are korelation positively and significan of physical resilience bounce spiritual (X1) ability and manage stress (X2) and also mount trust of x'self (X3) of with work motivation (Y). Pursuant to the result, hence therapy to improve motivation work to free improvement effort in overcoming barricade, trust play role the vitallyness. Despitefully the effort improvement of ability work that is by education and practice. Sincerity factor is seems needed to inculcate. Trust of x'self will generate bravery to try to explore to step into new area.
\end{abstract}

Keywords: Physical resilience bounce spiritual, Ability and manage stress, Munt trust of x'self \& work motivation

\begin{abstract}
Abstrak: Penelitian ini mengangkat permasalahan: Apakah ada hubungan secara parsial maupun secara bersama-sama antara ketahanan fisik mental spiritual (X1) dan kemampuan mengelola stress (X2) serta tingkat kepercayaan diri (X3)dengan motivasi kerja (Y). Penelitian ini bertujuan untuk dapat mengetahui secara parsial maupun secara variabel terikat(Y) dengan variabel bebas (X). Hasil penelitian menunjukkan bahwa secara parsial maupun secara bersama-sama ada hubungan secara positif dan significan antara ketahanan fisik mental spiritual (X1) dan kemampuan mengelola stress (X2) serta tingkat kepercayaan diri (X3) dengan motivasi kerja (Y). Berdasarkan hasil tersebut, maka terapi untuk meningkatkan motivasi kerja melalui upaya peningkatan bebas dalam mengatasi rintangan, kepercayaan memainkan peranan yang amat penting. Di samping itu usaha peningkatan kemampuan bekerja yaitu dengan pendidikan dan latihan. Faktor kejujuran tampaknya perlu ditanamkan. Kepercayaan diri akan menimbulkan keberanian untuk mencoba menjelajah masuk ke daerah baru.
\end{abstract}

Kata Kunci: Ketahanan fisik mental spiritual, Kemampuan mengelola stress, Tingkat kepercayaan diri, Motivasi kerja

\section{PENDAHULUAN}

Hotel merupakan salah satu unsur pariwisata yang mempunyai peranan sangat besar dalam memberikan pelayanan bagi wisatawan. Hotel bukanlah suatu tujuan bagi wisatawan, tetapi hotel merupakan pangkalan untuk beristirahat dan mengatur kelanjutan perjalanan serta kegiatannya. Oleh karena itu hotel dengan berbagai fasilitasnya harus 
mampu memenuhi kebutuhan wisatawan, dan jika pelayanannya tidak memuaskan wisatawan maka hotel akan menjadi gudang keluhan ( Complaint ).

Perhotelan merupakan salah satu industri dalam bidang kepariwisataan yang memegang peranan penting dalam upaya menarik wisatawan baik domistik maupun asing. Menurut Keputusan Menteri Pariwisata, Pos dan Telekomunikasi No. KM. 37/PW.304/MPPT - 86.

Hotel adalah suatu jenis akomodasi yang mempergunakan sebagian atau keseluruhan bangunan untuk menyediakan jasa penginapan, makan, minum dan jasa lainnya bagi umum yang dikelola secara komersial.

Industri pariwisata bidang perhotelan telah mempunyai bentuk hukum sehingga hotel mempunyai kewajiban yang sama dengan industri pariwisata bidang-bidang lainnya, yaitu harus mampu mandiri melalui peningkatan efisiensi guna menjamin pengembangannya menjadi usaha yang tangguh. Program pengembangan di bidang kepariwisataan, dekade kunjungan Indonesia 2007-2015 merupakan usaha untuk meningkatkan jumlah wisatawan. Hal ini memberikan harapan bahwa industri perhotelan khususnya di kabupaten/kota Solo, akan sangat menggembirakan. Hasil penelitian/pengamatan pendahuluan memberikan gambaran tentang tingkat hunian kamar( Occupancy rate ) hotel berbintang tiga sampai dengan lima adalah sangat bervariasi. rata-rata tingkat hunian kamar hotel di kabupaten/kota Solo 75,6\%., Bisnis perhotelan merupakan salah satu industri dalam bidang kepariwisataan yang memegang peranan penting dalam upaya menarik wisatawan baik domestik maupun asing. Berdasarkan data pra penelitian di atas, masalah yang menarik adalah tingkat hunian yang rendah. Tingkat hunian akan dapat mempengaruhi pencapaian tingkat keuntungan/profit. Rumus umum persamaan keuntungan/profit dalam bisnis di semua kegiatan bisnis adalah Profit $=$ Revenue - Cost. Melihat kondisi tingkat hunian seperti tersebut di atas, di dapat gambaran bahwa produktivitas bisnis hotel rata-rata sedang, maka hal ini tentunya sangat berkaitan dengan motivasi kerja para pekerja/petugas front office

Berdasarkan uraian latar belakang tersebut di atas, maka dapat dirumuskan permasalahan penelitian adalah sebagai berikut: (1) Apakah terdapat hubungan antara ketahanan fisik, mental, spiritual dengan motivasi kerja para pekerja/petugas front office; (2) Apakah terdapat hubungan antara kemampuan mengelola stres dengan motivasi kerja para pekerja/petugas front office; (3) Apakah terdapat hubungan antara tingkat percaya diri dengan motivasi kerja para pekerja/petugas front office; (4) Apakah terdapat hubungan antara ketahanan fisik, mental, spiritual dan kemampuan mengelola stres serta tingkat percaya diri secara bersama-sama dengan motivasi kerja para pekerja/petugas front office.

\section{KAJIAN TEORI}

Sesuai dengan uraian sebagaimana dikemukakan sebelumnya pada judul penelitian, latar belakang dan identifikasi serta rumusan masalah di atas, maka pada penelitian ini, peneliti membatasi pada variabel-variabel: ketahanan fisik mental spiritual (X1) dan kemampuan mengelola stress (X2) serta tingkat kepercayaan diri (X3)dengan motivasi kerja (Y)., yang nantinya akan dianalisis hubungan/korelasional secara parsial maupun secara bersama-sama dan penelitian akan dilakukan hanya pada perusahaan jasa perhotelan di daerah kabupaten/kota Solo. 
Ketahanan fisik, mental, spiritual merupakan kemampuan seseorang untuk menguasai kemalangan. Seseorang yang dapat menguasai dan mengatasi kemalangan akan mencapai keberhasilan Nelson (2001:1). Selanjutnya Kelly (1993:399) menyatakan bahwa kondisi yang sulit akan memberikan tantangan kepada manusia untuk berbuat kehidupannya berharga dan mereka harus menerima tanggungjawab untuk membuat pilihan-pilihan dan mengarahkan nasib mereka sendiri, selanjutnya bahwa orang yang melepaskan tanggungjawab adalah sikap yang tidak jujur dan tidak realistik, hal ini menunjukkan bahwa keyakinan yang buruk dan akhirnya akan hidup dalam keputusasaan.

Dari batasan tersebut mengandung pengertian bahwa ketahanan fisik, mental, spiritual sebagai ukuran kemampuan seseorang menguasai kemalangan dari berbagai tantangan yang dihadapinya untuk membuat kehidupannya menjadi lebih berguna sesuai dengan job deskripsinya. Untuk membangun tanggungjawab orang perlu memiliki tanggungjawab, bagaimana orang akan bertanggungjawab bila tidak pernah melakukannya dan untuk belajar bertanggungjawab akan lebih efektif jika delakukan dengan menggunakan pendekatan belajar sambil bekerja, karena dengan pendekatan ini seseorang akan membangun tiga aspek karakter sekaligus yaitu: pengetahuan, perasaan dan tindakan, yang dapat menjamin pemahaman yang mendalam terhadap tanggungjawab itu sendiri.

Hakekat Ketahanan Fisik, Mental, Spiritual. Menurut Nelson (2001:1) Ketahanan fisik, mental, spiritual merupakan kemampuan seseorang untuk menguasai kemalangan. Seseorang yang dapat menguasai dan mengatasi kemalangan akan mencapai keberhasilan. Selanjutnya Kelly (1993:399) menyatakan bahwa kondisi yang sulit akan memberikan tantangan kepada manusia untuk berbuat kehidupannya berharga dan mereka harus menerima tanggungjawab untuk membuat pilihan-pilihan dan mengarahkan nasib mereka sendiri, selanjutnya bahwa orang yang melepaskan tanggungjawab adalah sikap yang tidak jujur dan tidak realistik, hal ini menunjukkan bahwa keyakinan yang buruk dan akhirnya akan hidup dalam keputusasaan. Dari pengertian tersebut, dapat dikatakan bahwa ketahanan fisik, mental, spiritual sebagai ukuran kemampuan seseorang menguasai kemalangan dari berbagai tantangan yang dihadapinya untuk membuat kehidupannya menjadi lebih berguna sesuai dengan job deskripsinya. Untuk membangun tanggungjawab orang perlu memiliki tanggungjawab, bagaimana orang akan bertanggungjawab bila tidak pernah melakukannya dan untuk belajar bertanggungjawab akan lebih efektif jika delakukan dengan menggunakan pendekatan belajar sambil bekerja, karena dengan pendekatan ini seseorang akan membangun tiga aspek karakter sekaligus yaitu: pengetahuan, perasaan dan tindakan, yang dapat menjamin pemahaman yang mendalam terhadap tanggungjawab itu sendiri. Manusia pada hakekatnya adalah selalu berorientasi pada masa depan daripada masa lalunya, yang juga memberi implikasi bahwa manusia akan selalu diuji dalam mengantisipasi dan mengontrol kejadian masa depan dengan harapan agar masa depan dapat dipresentasikan dengan lebih baik. Oleh karena itu, manusia harus mempunyai kemampuan untuk mempresen- tasikan secara aktif dari pada meresponnya secara pasif. Untuk itu dalam melakukan pekerjaan perlu diperhatikan dan diisi dengan suatu perjuangan meningkatkan ketahanan fisik,mental, spiritual dalam memahami dunia kerja. Berdasar uraian tersebut, dalam penelitian ini ketahanan fisik,mental, spiritual responden adalah ketahanan dalam menghadapi berbagai hambatan dan kesulitan-kesulitan yang dihadapi dengan indikator: Ketahan dalam bekerja 
(ketekunan), ketahanan dalam menghadapi pesaing (daya saing), Ketahanan dalam menghadapai kompetisi (tantangan) dan ketahanan dalam masa depan (perubahan).

Kemampuan mengelola Stres adalah ciri dari sesuatu yang disyahkan pada diri seseorang untuk melakukan sesuatu yang berhubungan dengan kecakapan mental dan fisik. Faktor kemampuan mengelola Stres mencakup kecerdasan, pelatihan dan pengalaman. Hersey dan Blanchard (1988:7) menyatakan bahwa sedikitnya ada tiga ranah kemampuan manajerial yaitu: (1). Kemampuan teknis, kemampuan untuk menggunakan pengetahuan, metode, teknik dan perlengkapan yang dibutuhkan bagi pelaksanaan tugas khusus yang didapat melalui pengalaman, pendidikan dan pelatihan. (2). Kemampuan kemanusiaan, kemampuan dan penilaian dalam kerja melalui manusia. (3). Kemampuan konseptual, kemampuan untuk memahami kompleksitas dari seluruh organisasi, di mana seseorang akan cocok melakukan pekerjaannya.Selanjutnya George dan Jones (1996:252), Mendifinisikan Stess sebagai peluang atau ancaman yang dianggap sebagai suatu hal yang penting tetapi kemungkinan tidak dapat dilakukan secara efektif. Pertama stess dapat dialami karena dua sebab yakni : peluang adalah sesuatu yang mempunyai potensi mendatangkan keuntungan bagi seseoarang. Ancaman adalah sesuatu yang mempunyai potensi untuk melukai seseorang. Peluang dimaksud seperti belajar ketrampilan baru atau mendapat pekerjaan baru atau mendapat pekerjaan baru yang bisa mendatangkan stres. Bertitik tolak dari hal tersebut, maka dimaksud dengan kemampuan mengelola stres dalam penelitian ini adalah kesanggupan mengatasi dan mengatur diri pada suatu keadaan atau tuntutan yang dikehendaki sehingga pekerjaan tetap dapat diselesaikan dengan indikator: (1) mampu menciptakan suasana kerja kelompok yang baik, (2). Mampu melaksanakan tugas pekerjaan dan (3). Mampu menjaga kondisi fisik dan fisiologis yang prima.

Hakekat Kemampuan Mengelola Stres. Gibson, H. Donnelly (1997:94) kemampuan adalah ciri dari sesuatu yang disyahkan pada diri seseorang untuk melakukan sesuatu yang berhubungan dengan kecakapan mental dan fisik. Faktor kemampuan mencakup kecerdasan, pelatihan dan pengalaman. Kemampuan berb eda dengan motivasi, motivasi adalah kemauan untuk meraih produktivitas. Perbedaan antara kemampuan dengan motivasi merupakan hal yang penting karena tergantung pada sumber masalah dan pemecahan masalahnya. Prinsip umum pemecahan masalah, masalah seharusnya tidak dipecahkan dengan pemecahan masalah motivasi, sebaliknya masalah motivasi seharusnya tidak dipecahkan dengan pemecahan masalah kemampuan.

Hersey dan Blanchard (1988:7) menyatakan bahwa sedikitnya ada tiga ranah kemampuan manajerial yaitu: (1). Kemampuan teknis, kemampuan untuk menggunakan pengetahuan, metode, teknik dan perlengkapan yang dibutuhkan bagi pelaksanaan tugas khusus yang didapat melalui pengalaman, pendidikan dan pelatihan. (2). Kemampuan kemanusiaan, kemampuan dan penilaian dalam kerja melalui manusia. (3). Kemampuan konseptual, kemampuan untuk memahami kompleksitas dari seluruh organisasi, di mana seseorang akan cocok melakukan pekerjaannya.

George dan Jones (1996:252), Mendifinisikan Stess sebagai peluang atau ancaman yang dianggap sebagai suatu hal yang penting tetapi kemungkinan tidak dapat dilakukan secara efektif. Pertama stess dapat dialami karena dua sebab yakni : peluang adalah sesuatu yang mempunyai potensi mendatangkan keuntungan bagi seseoarang. Ancaman adalah sesuatu yang mempunyai potensi untuk melukai seseorang. Peluang dimaksud 
seperti belajar ketrampilan baru atau mendapat pekerjaan baru atau mendapat pekerjaan baru yang bisa mendatangkan stres.

Berdasar uraian di atas, maka banyak cara untuk mengelola stres yang ditawarkan oleh penyedia jasa, terutama di kota-kota kabupaten yaitu antara lain: meminimkan efek konsekuensi jasmani melalui kelegaan sementara; memperkuat kemampuan orang untuk mengatasi konsekuensi jasmani berdasarkan basis jangka panjang; mengintepretasikan peristiwa-peristiwa dalam kehidupan sihingga dapat menyingkirkan konsekuensi mental, emosional, relasional dan spiritual yang negatif agar dapat hidup panjang dengan damai; menaksirkan kembali situasi; mengatasi secara langsung masalah-masalah yang menjadi sumber stress. Bertitik tolak dari hal tersebut, maka dimaksud dengan kemampuan mengelola stres dalam penelitian ini adalah kesanggupan mengatasi dan mengatur diri pada suatu keadaan atau tuntutan yang dikehendaki sehingga pekerjaan tetap dapat diselesaikan dengan indikator : (1) mampu menciptakan suasana kerja kelompok yang baik, (2). Mampu melaksanakan tugas pekerjaan dan (3). Mampu menjaga kondisi fisik dan fisiologis yang prima.

Kepercayaan diri adalah modal dari aktualisasi sebagai bekal untuk sukses. Prinsip kepercayaan diri pada setiap orang perlu mengembangkan kepercayaan (confidence) untuk bergantung pada pengamatan diri sendiri, pada kemampuan sendiri untuk menenukan makna segala sesuatu ditengah-tengah kekacauan, kehati-hatian yang didasarkan pada kepercayaan diri sendiri untuk memperhatikan hal-hal yang berharga disekitarnya.. George (1996:360). Selanjutnya Robbins (2005:167), Penghalang kepercayaan diri adalah ketakutan untuk berinteraksi dengan orang lain. Hal demikian dikenal sebagai Communication apprehension yaitu jika berkomunikasi akan menarik diri dalam pergaulan, dan sekecil mungkin untuk berkomunikasi dan hanya berbicara apabila terdesak.

Dari uraian tersebut di atas, rasa percaya diri merupakan kesediaan untuk mencapai bergantung pada para pekerja (diri sendiri). Dalam penelitian ini dimaksud percaya diri adalah kemampuan para pekerja dalam melaksanakan pekerjaan sesuai dengan tujuannya, dengan idikator: (1) keyakinan, (2) respon, (3) kesanggupan bekerja, (4). Jujur, (5). Siap menghadapi kenyataan.

Hakekat Tingkat Kepercayaan Diri. Kemampuan untuk meraih cita-cita, adalah didorong oleh rasa percaya diri yang terbentuk oleh kemampuan mengembangkan kemampuan, belajar dari kekecewaan dan kesalahan, kemudian menikmati keberhasilan yang diraihnya.George (1996:360) Kepercayaan diri adalah modal dari aktualisasi sebagai bekal untuk sukses. Prinsip kepercayaan diri pada setiap orang perlu mengembangkan kepercayaan (confidence) untuk bergantung pada pengamatan diri sendiri, pada kemampuan sendiri untuk menenukan makna segala sesuatu ditengah-tengah kekacauan, kehati-hatian yang didasarkan pada kepercayaan diri sendiri untuk memperhatikan hal-hal yang berharga disekitarnya.

Robbins (2005:167), Penghalang dari percaya diri adalah ketakutan untuk berinteraksi dengan orang lain. Hal demikian dikenal sebagai Communication apprehension yaitu jika berkomunikasi akan menarik diri dalam pergaulan, dan sekecil mungkin untuk berkomunikasi dan hanya berbicara apabila terdesak. Robbins selanjutnya mengenalkan istilah self-efficacy yang diartikan sama dengan percaya diri, self-efficacy yang rendah akan menurunkan usahanya dalam mencapai tujuan sebelum nantinya menyerah dan 
tujuan tidak tercapai. Bagi yang mempunyai self - efficacy akan selalu mencoba menaklukkan rintangan yang dihadapinya secara keras, berusaha sekuatnya untuk mengatasi tantangan yang ada. Dari uraian tersebut di atas, rasa percaya diri merupakan kesediaan untuk mencapai bergantung pada para pekerja (diri sendiri). Dalam penelitian ini dimaksud percaya diri adalah kemampuan para pekerja dalam melaksanakan pekerjaan sesuai dengan tujuannya, dengan idikator: (1) keyakinan, (2) respon, (3) kesanggupan bekerja, (4). Jujur, (5). Siap menghadapi kenyataan.

Motivasi merupakan sebuah hal yang sangat komplek. Motivasi melibatkan perasaan, pikiran dan pengalaman-pengalaman masa lalu yang dirasakan oleh orang-orang di dalam organisasi. Motivasi sebagai penggerak seseorang untuk melakukan sesuatu karena orang tersebut memang ingin melakukannya. Orang akan bertindak karena merasa bahwa mereka memang harus bertindak. Namun apabila mereka termotivasi maka mereka akan melakukan hal-hal yang positif saja karena kemungkinan hal-hal yang positif tersebut akan memuaskan kebutuhannya. Keith Davis (1996:501), selanjutnya Shermerhorn dan Osbom (1997:87), Motivasi adalah kekuatan dalam diri seseorang yang berperan untuk menentukan arah, tingkat dan ketekunan dari usaha yang dilakukan di tempat kerja. Untuk mengetahui tingkat motivasi seseorang maka teori Maslow akan menjadi panduan pengukuran Motivasi.

Berdasar uraian di atas dalam penelitian ini yang dimaksud motivasi adalah dorongan yang bersumber dari dalam diri pekerja untuk mencapai hasil yan g optimal dengan indikator: (1). Tanggungjawab; (2). Berani menghadapi risiko; (3). Dapat mengatasi masalah; (4). Ingin berhasil dalam bekerja.

Hakekat Motivasi Kerja. Keith Davis (1996:501), Motivasi merupakan sebuah hal yang sangat komplek. Motivasi melibatkan perasaan, pikiran dan pengalaman-pengalaman masa lalu yang dirasakan oleh orang-orang di dalam organisasi. Motivasi sebagai penggerak seseorang untuk melakukan sesuatu karena orang tersebut memang ingin melakukannya. Orang akan bertindak karena merasa bahwa mereka memang harus bertindak. Namun apabila mereka termotivasi maka mereka akan melakukan hal-hal yang positif saja karena kemungkinan hal-hal yang positif tersebut akan memuaskan kebutuhannya.

Shermerhorn dan Osbom (1997:87), Motivasi adalah kekuatan dalam diri seseorang yang berperan untuk menentukan arah, tingkat dan ketekunan dari usaha yang dilakukan di tempat kerja. Untuk mengetahui tingkat motivasi seseorang maka teori Maslow akan menjadi panduan pengukuran Motivasi dalam penelitian ini didasarkan pada asumsi utama yaitu: (1). Sejauh mana harapan pekerja dapat dipenuhi oleh organisasi;(2). Apa yang dip[ikirkan oleh pekerja mengenai peluang mereka dalam organisasi;(3). Bagaimana pendapat pekerja mengenai seberapa banyak pemenuhan kebutuhannya diperoleh dari organisasinya dan (4) bagaimana persepsi pekerja mengenai kinerja mereka dalam organisasi. Berdasar uraian di atas dalam penelitian ini yang dimaksud motivasi adalah dorongan yang bersumber dari dalam diri pekerja untuk mencapai hasil yan g optimal dengan indikator: (1). Tanggungjawab; (2). Berani menghadapi risiko; (3). Dapat mengatasi masalah; (4). Ingin berhasil dalam bekerja.

Hubungan antara ketahanan fisik mental spiritual dengan motivasi kerja. Kondisi ketahanan fisik mental spiritual dan motivasi kerja, apabila motivasi kerja seseorang lemah, maka orang tersebut dapat bertingkahlaku anti social. Namun apabila motivasi 
kerja seseorang terlalu kuat, maka orang tersebut dapat mengubur keasliannya dan akan berusaha keras untuk menemukan dan melakukan hal-hal yang benar. Untuk mencapai tujuan dari sesuatu yang diinginkan, orang akan berusaha untuk "Stay in shape" sehingga segala hal yang menghalangi sedapat mungkin disingkirkan. Jadi apabila motivasi seseorang begitu kuatnya, maka ia akan mampu untuk mengendalikan stress yang dimilikinya sehingga dapat meraih kesuksesan dalam bekerja, tetapi jika motivasi kerjanya rendah, maka pekerja akan membiarkan stress social maupun stress ditempat kerjanya berkesinambungan sehingga pada saatnya akan terakumulasi menjadi hal yang merusak baik mental maupun fisiknya.

Hubungan antara kemampuan mengelola stres dengan motivasi kerja. Sehubungan dengan sifat seorang pekerja pada umumnya, jika seseorang memiliki sifat keras kepala, tidak menyerah begitu saja dan semakin terdorong untuk meresponnya. Apabila kegiatan dan aktivitasnya dihalangi atau terhalang, maka pekerja akan meronta dan akan menjadi tegar. Dari pola tingkah laku ini, motivasi bidang kerjanya akan berkembang dan akan muncul stimulus-stimulus baru yang akan meningkatkan kinerjanya. Apabila pekerja mempunyai motivasi kerja untuk penguasaan bidang tugasnya atau motivasinya lebih unggul daripada pekerja lain, maka pekerja tersebut mempunyai nilai lebih Value Added . Pada dasarnya para pekerja sebagai sumber daya manusia/insani selalu berusaha untuk mampu secara terus menerus melakukan pekerjaannya sampai selesai dan secara alamiah akan menanggulanginya.

Hubungan antara tingkat kepercayaan diri dengan motivasi kerja. Kondisi tingkat kepercayaan diri dan motivasi kerja. Dalam suatu kehidupan kerja seseorang yang mempunyai kepercayaan diri yang tinggi tentu akan memandang hidup lebih mudah ditaklukkan, artinya stress kerja dapat dikelola dengan baik atau dengan kata lain bahwa semakin kuat rasa percaya diri para pekerja, berarti semakin kuat motivasi kerjanya.

Hubungan antara ketahanan fisik mental spiritual dan kemampuan mengelola stres serta tingkat kepercayaan diri dengan motivasi kerja. Dari kerangka pemikiran di atas, maka dapat diduga bahwa terdapat hubungan yang positif antara ketahanan fisik mental spiritual dan kemampuan mengelola stres serta tingkat kepercayaan diri dengan motivasi kerja. Atau dengan kata lain semakin kuat kemampuan mengelola stress, makin kuat ketahanan fisik mental spiritual dan makin kuat rasa percaya diri secara bersamasama, makin kuat pula motivasi kerja dalam melaksanakan tugas pekerjaannya.

Berdasar kajian teori dan penelitian terdahulu serta kerangka pemikiran seperti uraian tersebut di atas, maka skema sebagai kerangka penelitian dapat digambarkan sebagai berikut: 


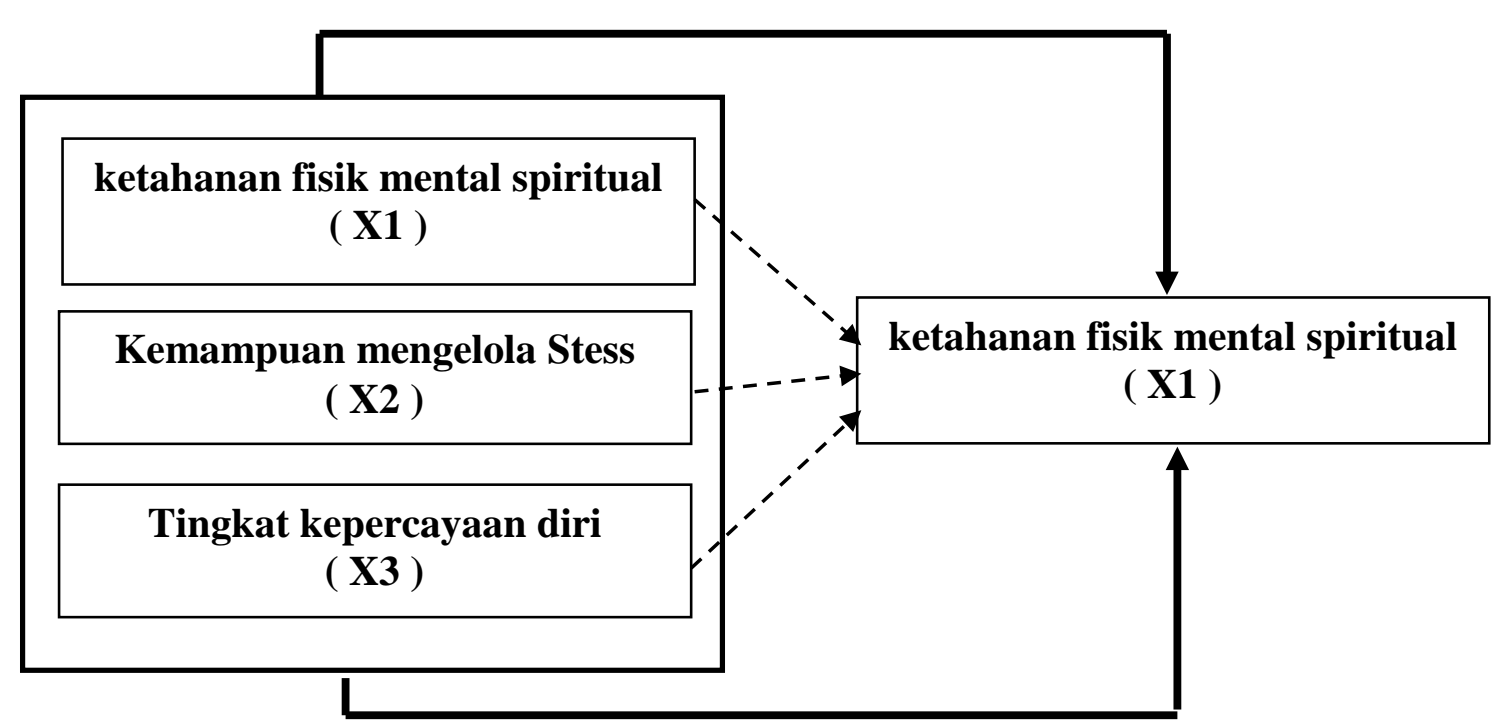

Gambar 1. Kerangka Penelitian

Pola hubungan antar variable $\mathrm{X}$ dengan $\mathrm{Y}$

Keterangan:

............. Hubungan/korelasional secara parsial

$\longrightarrow$ Hubungan/korelasional secara bersama-sama

Hipotesis Penelitian. Berdasarkan penelitian terdahulu dan Kerangka penelitian yang telah dijelaskan seperti gambar tersebut di atas, maka hipotesis penelitian dapat dirumuskan sebagai berikut: (1) Terdapat hubungan yang signifikan antara ketahanan fisik mental spiritual dengan motivasi kerja; (2) Terdapat hubungan yang signifikan antara kemampuan mengelola stress dengan motivasi kerja; (3) Terdapat hubungan yang signifikan antara tingkat kepercayaan diri dengan motivasi kerja; (4)Terdapat hubungan yang signifikan antara ketahanan fisik mental spiritual dan kemampuan mengelola stres serta tingkat kepercayaan diri secara bersama-sama dengan motivasi kerja.

\section{METODE}

Berangkat dari tujuan penelitian yang pada intinya adalah untuk melakukan pengujian hipotesis, jenis penelitian ini adalah penelitian deskriptif analitis,verifikatif (kausalitas), maka metode yang dipakai dalam penelitian ini, adalah metode survai, unit analisis adalah karyawan/para petugas front office, sifat penelitian adalah cross sectional. Dengan Objek Penelitian dilakukan pada usaha bisnis jasa perhotelan dengan klasifikasi hotel berbintang tiga sampai dengan lima di kabupaten/kota Solo. Sumber data dalam penelitian ini bersumber pada data sekunder data primer. Data sekunder digunakan dalam penelitian ini bersumber dari kantor statistik setempat dan Statistik Indonesia yang berkaitan dengan perhotelan. Sedangkan data primer bersumber pada kuesioner yang telah disebarkan kepada responden. Responden dalam penelitian ini sejumlah 63 orang responden. Yaitu petugas front office, penelitian ini tidak melakukan pengambilan 
sampel, untuk mencapai sasaran analisis digunakan metode sensus yaitu semua unit dalam populasi sebagai unit sasaran. Analisis Data, untuk mendapatkan hasil penelitian yang rasional dan dapat dipertanggungjawabkan, maka dilakukan langkah-langkah sebagai berikut: Pertama. Analisis Butir. Pelaksanaan analisis butir (uji tingkat kesahihan/validitas butir, dan uji keandalan/ reliabilitas butir serta uji kesahihan/validitas faktor) dilakukan dengan olahan data Seri Program Statistik (SPS), oleh karena pemrosesan data dengan bantuan program komputer,maka taraf signifikansi dalam analisis butir berdasar Kaidah Uji Hipotesis Alternatif Penelitian (KUHAP) sebagai berikut:

Tabel 1. KUHAP ALTERNATIF

\begin{tabular}{ccl}
\hline Nomor & Kondisi Peluang Galat & Taraf Signifikansi \\
\hline 1 & $\mathrm{p}<0.01$ & Sangat signifikan \\
2 & $\mathrm{p}<0.05$ & Signifikan \\
3 & $\mathrm{p}<0.15$ & Cukup Signifikan \\
4 & $\mathrm{p}<0.30$ & Kurang Signifikan \\
5 & $\mathrm{p}>0.30$ & Tidak/Nir Signifikan \\
\hline
\end{tabular}

Kedua. Uji Kesahihan/Validitas Butir. Uji Kesahihan/Validitas Butir terhadap item2 yang berbaikan dengan: (a) Hubungan antara ketahanan fisik mental spiritual dengan motivasi kerja, (b) Hubungan antara kemampuan mengelola stres dengan motivasi kerja, (c) Hubungan antara tingkat kepercayaan diri dengan motivasi kerja.

Ketiga. Uji Keandalan/Reliabilitas Butir. Uji Keandalan/Reliabilitas Butir terhadap item2 yang berbaikan dengan: (a) Faktor pertama yaitu peran pengetahuan operasional petugas front office terhadap optimalisasi produktivitas kerja, (b) Faktor ke dua yaitu peran motivasi kerja petugas front office terhadap optimalisasi produktivitas kerja, (c) Faktor ke tiga yaitu peran kepuasan kerja petugas front office terhadap optimalisasi produktivitas kerja. Keempat. Uji Kesahihan/Validitas Faktor. Uji Kesahihan/Validitas Faktor yang berbaikan dengan: Mengamati korelasi faktor konstrak dan sumbangan efektif, Selanjutnya setelah persyaratan analisis butir yaitu: validitas butir, reliabilitas butir, dan validitas faktor dinyatakan telah terpenuhi, maka untuk analisis data hasil penelitian tersebut akan dilakukan peningkatan pengukuran terlebih dahulu terhadap data dari ukuran/skala ordinal menjadi ukuran/skala interval. Hasil peningkatan pengukuran data tersebut selanjutnya sebagai masukkan (input) dalam melakukan analisis korelasional. Untuk mendapat hasil yang dapat dipertanggungjawabkan, maka terlebih dahulu perlu dilakukan uji asumsi.

Uji Asumsi. Uji asumsi dilakukan dengan uji normalitas sebaran dan uji linieritas hubungan. Uji asumsi yang dimaksud adalah sebagai berikut: (1) Uji Normalitas Sebaran. Dalam melakukan uji normalitas sebaran berdasar pada kaidah jika $\mathrm{p}>0,01$ sebaran dinyatakan normal, dan sebaliknya jika $\mathrm{p}<0,01$ dan sebaran dinyatakan tidak normal pada tingkat $\alpha=0,01$ (uji satu ekor). (2) Uji Linieritas Hubungan. Dalam melakukan uji linieritas hubungan berdasar pada kaidah jika $\mathrm{p}$ beda $>0,01$ derajat hubungannya dinyatakan linier dan jika p beda $<0,01$ dan derajat hubungannya dinyatakan tidak linier pada tingkat $\alpha=0,01$., Selanjutnya peneliti perlu terlebih dahulu 
melakukan pengujian persyaratan analisis. Persyaratan yang harus dipenuhi dalam teknik analisis korelasional meliputi: Uji Normalitas dan Uji Homoginitas.

Analisis Korelasi dengan bantuan program Statistik (SPS). Operasionalisasi variabel. Berdasarkan uraian dalam kerangka pemikiran dan hipotesis penelitian maka variabel penelitian terdiri dari tiga variabel indipenden yaitu: Ketahanan Fisik Mental Spiritual ( X1 )., Kemampuan mengelola Stress (X2 )., Tingkat Kepercayaan Diri (X3 ), dan satu variabel dependen yaitu Motivasi Kerja ( Y ).

Hubungan antara ketahanan fisik mental spiritual (X1) dengan motivasi kerja (Y). Kondisi ketahanan fisik mental spiritual dan motivasi kerja, apabila motivasi kerja seseorang lemah, maka orang tersebut dapat bertingkahlaku anti social. Namun apabila motivasi kerja seseorang terlalu kuat, maka orang tersebut dapat mengubur keasliannya dan akan berusaha keras untuk menemukan dan melakukan hal-hal yang benar. Untuk mencapai tujuan dari sesuatu yang diinginkan, orang akan berusaha untuk "Stay in shape" sehingga segala hal yang menghalangi sedapat mungkin disingkirkan. Jadi apabila motivasi seseorang begitu kuatnya, maka ia akan mampu untuk mengendalikan stress yang dimilikinya sehingga dapat meraih kesuksesan dalam bekerja, tetapi jika motivasi kerjanya rendah, maka pekerja akan membiarkan stress social maupun stress ditempat kerjanya berkesinambungan sehingga pada saatnya akan terakumulasi menjadi hal yang merusak baik mental maupun fisiknya.

Hubungan antara kemampuan mengelola stres (X2) dengan motivasi kerja (Y). Sehubungan dengan sifat seorang pekerja pada umumnya, jika seseorang memiliki sifat keras kepala, tidak menyerah begitu saja dan semakin terdorong untuk meresponnya. Apabila kegiatan dan aktivitasnya dihalangi atau terhalang, maka pekerja akan meronta dan akan menjadi tegar. Dari pola tingkah laku ini, motivasi bidang kerjanya akan berkembang dan akan muncul stimulus-stimulus baru yang akan meningkatkan kinerjanya. Apabila pekerja mempunyai motivasi kerja untuk penguasaan bidang tugasnya atau motivasinya lebih unggul daripada pekerja lain, maka pekerja tersebut mempunyai nilai lebih Value Added . Pada dasarnya para pekerja sebagai sumber daya manusia/insani selalu berusaha untuk mampu secara terus menerus melakukan pekerjaannya sampai selesai dan secara alamiah akan menanggulanginya.

Hubungan antara tingkat kepercayaan diri (X3) dengan motivasi kerja (Y). Kondisi tingkat kepercayaan diri dan motivasi kerja. Dalam suatu kehidupan kerja seseorang yang mempunyai kepercayaan diri yang tinggi tentu akan memandang hidup lebih mudah ditaklukkan, artinya stress kerja dapat dikelola dengan baik atau dengan kata lain bahwa semakin kuat rasa percaya diri para pekerja, berarti semakin kuat motivasi kerjanya.

Hubungan antara ketahanan fisik mental spiritual dan kemampuan mengelola stres serta tingkat kepercayaan diri (X1X2X3) dengan motivasi kerja (Y). Dari kerangka pemikiran di atas, maka dapat diduga bahwa terdapat hubungan yang positif antara ketahanan fisik mental spiritual dan kemampuan mengelola stres serta tingkat kepercayaan diri dengan motivasi kerja. Atau dengan kata lain semakin kuat kemampuan mengelola 
stress, makin kuat ketahanan fisik mental spiritual dan makin kuat rasa percaya diri secara bersama-sama, makin kuat pula motivasi kerja dalam melaksanakan tugas pekerjaannya.

Berdasarkan uraian tersebut di atas, maka dapat gambarkan kerangka/skema analisis penelitian adalah sebagai berikut:

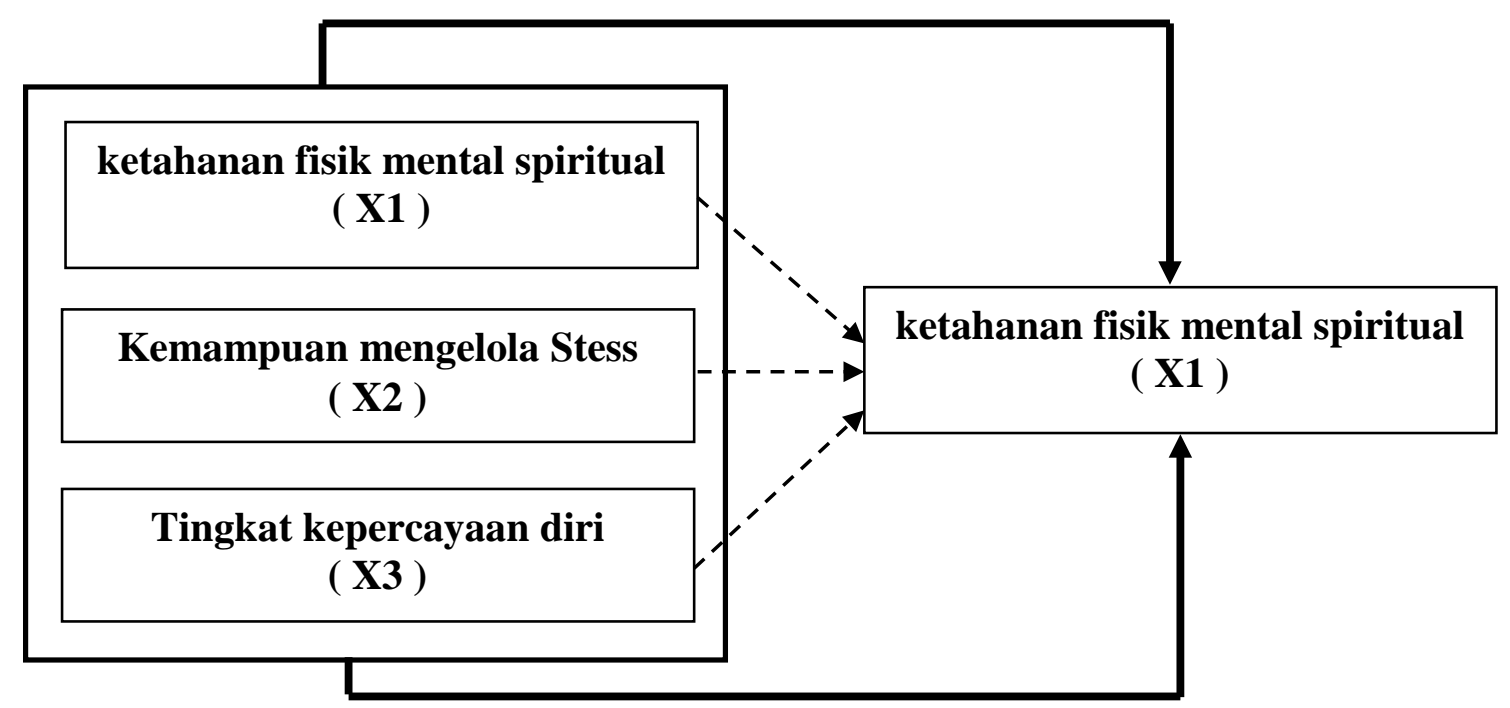

Gambar 2. Kerangka Analisis Penelitian

Pola hubungan antar variable $X$ dengan $Y$

Keterangan:

............. Hubungan/korelasional secara parsial

$\longrightarrow$ Hubungan/korelasional secara bersama-sama

\section{HASIL DAN PEMBAHASAN}

Untuk mendapatkan hasil penelitian yang rasional dan dapat dipertanggung jawabkan maka dilakukan langkah-langkah sebagai berikut:

Analisis Butir. Pelaksanaan analisis butir (uji tingkat kesahihan/validitas butir, dan uji keandalan/reliabilitas butir serta uji kesahihan/validitas faktor) dilakukan dengan olahan data Seri Program Statistik (SPS). oleh karena pemrosesan data dengan bantuan program komputer,maka taraf signifikansi dalam analisis butir berdasar Kaidah Uji Hipotesis Alternatif Penelitian (KUHAP) sebagai berikut:

Tabel 2. KUHAP ALTERNATIF

\begin{tabular}{ccl}
\hline Nomor & Kondisi Peluang Galat & Taraf Signifikansi \\
\hline 1 & $\mathrm{p}<0.01$ & Sangat Signifikan \\
2 & $\mathrm{p}<0.05$ & Signifikan \\
3 & $\mathrm{p}<0.15$ & Cukup Signifikan \\
4 & $\mathrm{p}<0.30$ & Kurang Signifikan \\
5 & $\mathrm{p}>0.30$ & Tidak/Nir Signifikan \\
\hline
\end{tabular}


Uji Kesahihan/Validitas Butir. Berdasarkan hasil perhitungan, didapat hasil sebagai berikut: Pertama. Hubungan antara ketahanan fisik mental spiritual (X1) dengan motivasi kerja (Y). Dinyatakan dalam item no. 1 s/d 30. Nilai rbt hitung pada butir 5,9,13,15,19 dan 28 adalah lebih kecil daripada nilai $r$ tabel sehingga item tersebut dinyatakan gugur, semua item tersebut tidak dipakai. Item yang dipakali untuk menggali informasi adalah sejumlah dua puluh empat item, ke dua puluh empat item tersebut menunjukkan nilai rbt hitung lebih besar daripada nilai $r$ tabel, dan nilai $p=0,000$ berarti item-item tersebut sangat signifikan. Item-item tersebut menunjukkan bahwa pertanyaan-pertanyaan untuk mengukur peran manajer dalam perencanaan dan pengendalian anggaran adalah valid, artinya para manajer tidak merasa sulit atau ragu-ragu untuk menjawab pertanyaan tentang perannya.

Kedua. Hubungan antara kemampuan mengelola stres (X2) dengan motivasi kerja (Y). Dinyatakan dalam item no. 31 s/d 46. Nilai rbt hitung pada butir 40 dan 44 adalah lebih kecil daripada nilai $r$ tabel sehingga item tersebut dinyatakan gugur, semua item tersebut tidak dipakai. Item yang dipakai untuk menggali informasi adalah sejumlah empat belas, ke empat belas item tersebut menunjukkan nilai rbt hitung lebih besar daripada nilai $r$ tabel, dan nilai $\mathrm{p}=0,000$ berarti item-item tersebut sangat signifikan. Item-item tersebut menunjukkan bahwa pertanyaan-pertanyaan untuk mengukur peran manajer dalam perencanaan dan pengendalian operasional usaha adalah valid, artinya para manajer tidak merasa sulit atau ragu-ragu untuk menjawab pertanyaan tentang perannya.

Ketiga. Hubungan antara tingkat kepercayaan diri (X3) dengan motivasi kerja (Y). Dinyatakan dalam item no. 47 s/d 78. Nilai rbt hitung pada butir 5,9,13,15,19,28,53,63,68,73,75,77 dan 78 adalah lebih kecil daripada nilai $r$ tabel sehingga item tersebut dinyatakan gugur, semua item tersebut tidak dipakai. Item yang dipakali untuk menggali informasi adalah sejumlah dua puluh lima, ke dua puluh lima item tersebut menunjukkan nilai rbt hitung lebih besar daripada nilai $r$ tabel, dan nilai $p=0,000$ berarti item-item tersebut sangat signifikan. Item-item tersebut menunjukkan bahwa pertanyaan-pertanyaan untuk mengukur tingkat efisiensi perhotelan adalah valid, artinya para manajer tidak merasa sulit atau ragu-ragu untuk menjawab pertanyaan tentang tingkat efisiensi.

Uji Keandalan/Reliabilitas Butir. Berdasarkan tabel rangkuman analisis. (1) Faktor pertama yaitu peran pengetahuan operasional Customer Service Office terhadap optimalisasi produktivitas kerja (24 item) menunjukkan bahwa ke dua puluh empat item tersebut mempunyai nilai rtt hitung sebesar 0,984 , nilai tersebut lebih besar daripada rtt tabel (pada $\mathrm{n}=30, \alpha=1 \%$ nilai $\mathrm{r}=0,463$ ), dan nilai $\mathrm{p}=0,000$ (sangat signifikan). Hal ini berarti semua item yang ada adalah andal/reliabel. (2) Faktor ke dua yaitu peran motivasi kerja Customer Service Office terhadap optimalisasi produktivitas kerja (14 item) menunjukkan bahwa ke empat belas item tersebut mempunyai nilai rtt hitung sebesar 0,972, nilai tersebut lebih besar daripada rtt tabel (pada $n=30, \alpha=1 \%$ nilai $r=0,463$ ), dan nilai $\mathrm{p}=0,000$ (sangat signifikan). Hal ini berarti semua item yang ada adalah andal/reliabel. (3) Faktor ke tiga yaitu peran kepuasan kerja Customer Service Office terhadap optimalisasi produktivitas kerja (25 item) menunjukkan bahwa ke dua puluh lima item tersebut mempunyai nilai rtt hitung sebesar 0,986, nilai tersebut lebih besar daripada rtt tabel (pada $n=30, \alpha=1 \%$ nilai $r=0,463$ ), dan nilai $p=0,000$ (sangat signifikan). Hal ini berarti semua item yang ada adalah andal/reliabel. 
Uji Kesahihan/Validitas Faktor. Berdasarkan tabel korelasi faktor konstrak dan sumbangan efektif, menunjukkan bahwa faktor pertama mempunyai nilai rbt hitung sebesar 0,999; faktor ke dua nilai rbt hitung sebesar 0,998, dan faktor ke tiga nilai rbt hitung sebesar 0,999 berarti semua nilai rbt dari ketiga faktor tersebut lebih besar daripada nilai rbt tabel (pada $n=30, \alpha=1 \%$ nilai $r=0,463$ ), dan persentase sumbangan efektif untuk faktor pertama adalah 38,15, faktor ke dua adalah 21,701, dan faktor ke tiga adalah 40,147 , serta ke tiga faktor tersebut mempunyai nilai $\mathrm{p}=0,000$. Hal tersebut mempunyai arti bahwa semua faktor yang ada adalah sahih/valid. Selanjutnya setelah persyaratan analisis butir yaitu: validitas butir, reliabilitas butir, dan validitas faktor dinyatakan telah terpenuhi, maka untuk analisis data hasil penelitian tersebut dilakukan peningkatan pengukuran terlebih dahulu terhadap data dari ukuran/skala ordinal menjadi ukuran/skala interval. Hasil peningkatan pengukuran data tersebut selanjutnya sebagai masukkan (input) dalam melakukan analisis korelasional. Untuk mendapat hasil yang dapat dipertanggungjawabkan, maka terlebih dahulu perlu dilakukan uji asumsi.

Uji Asumsi. Uji asumsi dilakukan dengan uji normalitas sebaran dan uji linieritas hubungan. Uji asumsi yang dimaksud adalah sebagai berikut: Pertama. Uji Normalitas Sebaran. Dalam melakukan uji normalitas sebaran berdasar pada kaidah jika p>0,01 sebaran dinyatakan normal, dan sebaliknya jika $\mathrm{p}<0,01$ sebaran dinyatakan tidak normal pada tingkat $\alpha=0,01$ (uji satu ekor). hasil uji normalitas menunjukkan nilai Kai Kuadrat $(K K)=8.525$, dengan derajad bebas $d b=6$ menghasilkan peluang ralat $(p)=0.202$. yang berarti tidak ada perbedaan yang signifikan antara frekuensi empiris (yang diamati) dengan frekuensi teoritis dari kurve normal, oleh karena itu perhitungan ini menyimpulkan bahwa normalitas sebaran dinyatakan normal (uji normalitas terpenuhi).

Kedua. Uji Linieritas Hubungan. Dalam melakukan uji linieritas hubungan berdasar pada kaidah jika p beda $>0,01$ derajat hubungannya dinyatakan linier dan jika p beda < 0,01 derajat hubungannya dinyatakan tidak linier pada tingkat $\alpha=0,01$., linieritas hubungan variabel $\mathrm{X}_{1}$ dengan $\mathrm{Y}$, nilai $\mathrm{F}$ hitung lebih besar $\mathrm{F}$ tabel besarnya nilai peluang ralat (p) beda adalah sebesar 0,067. linieritas hubungan variabel $\mathrm{X}_{2}$ dengan $\mathrm{Y}$ besarnya nilai peluang ralat (p) beda adalah sebesar 0,960, linieritas hubungan variabel $\mathrm{X}_{3}$ dengan $\mathrm{Y}$ besarnya nilai peluang ralat (p) beda adalah sebesar 0,690 . Hal ini dapat menunjukan bahwa derajad hubungan variabel $\mathrm{X}_{1}, \mathrm{X}_{2}$ dan $\mathrm{X}_{3}$ dengan $\mathrm{Y}$ derajad hubungannya adalah linier (uji linieritas hubungan terpenuhi). Selanjutnya penulis perlu sajikan terlebih dahulu pengujian persyaratan analisis. Persyaratan yang harus dipenuhi dalam teknik analisis korelasional meliputi: Uji Normalitas dan Uji Homoginitas.

Dari data penelitian yang telah didapat maka dapat dirangkum dan dideskripsikan sehingga dapat disajikan seperti pada tabel sebagai berikut:

Tabel 3. Statistik data penelitian $(n=63$ )

\begin{tabular}{ccccc}
\hline Variabel & Rata-rata & Std. Deviasi & Median & Modus \\
\hline X1 & 98,17 & 7,08 & 99,0 & 99,00 \\
X2 & 107,37 & 4,02 & 107,50 & 104,00 \\
X3 & 109,35 & 8,20 & 109,00 & 116,00 \\
Y & 113,06 & 6,63 & 113 & 110,00 \\
\hline
\end{tabular}


Analisis Hubungan/Korelasi. Hubungan antara ketahanan fisik mental spiritual (X1) dengan motivasi kerja (Y), hasil perhitungan: apabila dilakukan pengontrolan terhadap variabel (X2), maka di dapat $\mathrm{r}_{\text {y1.2 }}=0,251$. Uji signifikansi dengan harga $\mathrm{t}$ hitung sebesar 2,04 dan harga $\mathrm{t}$ tabel sebesar 2,37 pada $\alpha=0,01$ adalah signifikan. Bila dilakukan pengontrolan terhadap (X2) didapat $\mathrm{r}_{\mathrm{y} 1 . .3}=0,236$. Uji signifikansi dengan uji t diperoleh harga $\mathrm{t}$ hitung sebesar 1,91 dan harga $\mathrm{t}$ tabel sebesar 1,66 pada $\alpha=0,05$, korelasi parsial signifikan. Dan jika dilakukan pengontrolan terhadap variabel (X1) dan variabel (X3) secara bersama-sama diperoleh koefisien korelasi parsial sebesar $\mathrm{r}$ y1.2 $3=0,198$ korelasi tidak signifikan. Hasil perhitungan korelasi parsial tersebut dapat disajikan seperti pada tabel sebagai berikut:

Tabel 4. Uji Sgnifikansi Koefisien Korelasi antara X1 dengan Y

\begin{tabular}{|c|c|c|c|c|c|}
\hline \multirow[t]{2}{*}{$\mathrm{n}$} & \multirow{2}{*}{$\begin{array}{c}\text { Koefisien } \\
\text { Korelasi } \\
r_{y 1}\end{array}$} & \multirow{2}{*}{$\begin{array}{l}\text { Koefisien } \\
\text { Determinasi } \\
\left(\mathrm{r}_{\mathrm{y} 1)^{2}}\right.\end{array}$} & \multirow[b]{2}{*}{$\mathrm{t}$ hitung } & \multicolumn{2}{|c|}{$\mathrm{t}_{\text {tabel }}$} \\
\hline & & & & 0,05 & 0,01 \\
\hline 63 & 0,60 & 0,36 & $5,95^{* *}$ & 1,66 & 2,37 \\
\hline
\end{tabular}

Tabel 5. Uji Sgnifikansi Koefisien Korelasi parsial antara X1 dengan Y

\begin{tabular}{cccc}
\hline Koefisien Korelasi & \multicolumn{2}{c}{$\mathrm{t}_{\text {tabel }}$} \\
Parsial & $\mathrm{t}_{\text {hitung }}$ & 0,05 & 0,01 \\
\hline $\mathrm{r}_{\mathrm{y} 1.2}=0,251$ & $2,04^{* *}$ & 1,66 & 2,37 \\
$\mathrm{r}_{\mathrm{y} 1.3}=0,236$ & $1,91^{*}$ & 1,66 & 2,37 \\
$\mathrm{r}_{\mathrm{y} 1.23}=0,198$ & $0,158^{\mathrm{NS}}$ & 1,66 & 2,37 \\
\hline
\end{tabular}

Keterangan: $* *=$ Koefisien Korelasi sangat signifikan $\left(\mathrm{t}\right.$ hitung $\left.>\mathrm{t}_{\text {tabel }}\right)$; ${ }^{\mathrm{NS}}=$ Koefisien Korelasi tidak signidfikan ( $\mathrm{t}$ hitung $<\mathrm{t}_{\text {tabel }}$ ); $\mathrm{r}_{\mathrm{y} 1.2}=$ Koefisien Korelasi parsial X1 dengan Y jika X2 dikontrol; $r_{\text {y1.3 }}=$ Koefisien Korelasi parsial X1 dengan Y jika X3 dikontrol; $r$ y1.23 = Koefisien Korelasi parsial X1 dengan Y jika X2 dan X3 dikontrol.

Hubungan antara kemampuan mengelola stres (X2) dengan motivasi kerja (Y) hasil perhitungan : apabila dilakukan pengontrolan terhadap variabel (X1) maka di dapat $\mathrm{r}_{\mathrm{y} 2.1}=$ 0,450. Uji signifikansi dengan harga $t$ hitung sebesar 3,97 dan harga $t$ tabel sebesar 2,37 pada $\alpha=0,01$ adalah signifikan. Bila dilakukan pengontrolan terhadap (X3) didapat $\mathrm{r}_{\mathrm{y} 2 . .3}=$ 0,175. Uji signifikansi dengan uji t diperoleh harga $t$ hitung sebesar 1,66 dan harga t tabel sebesar 1,40 pada $\alpha=0,05$, korelasi parsial menjadi tidak signifikan. Dan jika dilakukan pengontrolan terhadap variabel (X1) dan variabel (X3) secara bersama-sama diperoleh koefisien korelasi parsial sebesar $\mathrm{r}_{\text {y2.1 }} 3=0,116$ korelasi tidak signifikan. Hasil perhitungan korelasi parsial tersebut dapat disajikan seperti pada tabel sebagai berikut: 
Tabel 6. Uji Sgnifikansi Koefisien Korelasi antara X2 dengan Y

\begin{tabular}{cccccc}
$\mathrm{n}$ & $\begin{array}{c}\text { Koefisien } \\
\text { Korelasi } \\
\mathrm{r}_{\mathrm{y} 2}\end{array}$ & $\begin{array}{c}\text { Koefisien } \\
\text { Determinasi } \\
\left(\mathrm{r}_{\mathrm{y} 2)}{ }^{2}\right.\end{array}$ & $\mathrm{t}_{\text {hitung }}$ & 0,05 & 0,01 \\
\hline 63 & 0,497 & 0,247 & $4,55^{* *}$ & 1,66 & 2,37
\end{tabular}

Catatan : ** Koefisien sangat signifikan; $\mathrm{r}$ y2 Koefisien korelasi antara X2 dengan Y.

Tabel 7. Uji Sgnifikansi Koefisien Korelasi parsial antara X2 dengan Y

\begin{tabular}{ccrc}
\hline Koefisien Korelasi & & \multicolumn{2}{c}{$\mathrm{t}_{\text {tabel }}$} \\
\cline { 3 - 4 } Parsial & $\mathrm{t}_{\text {hitung }}$ & 0,05 & 0,01 \\
\hline $\mathrm{r}_{\mathrm{y} 2.1}=0,450$ & $3,97^{* *}$ & 1,66 & 2,37 \\
$\mathrm{r}_{\mathrm{y} 2.3}=0,175$ & $1,40^{\mathrm{NS}}$ & 1,66 & 2,37 \\
$\mathrm{r}_{\mathrm{y} 2.13}=0,116$ & $0,94^{\mathrm{NS}}$ & 1,66 & 2,37 \\
\hline
\end{tabular}

Keterangan: $* *=$ Koefisien Korelasi sangat signifikan $\left(\mathrm{t}\right.$ hitung $\left.>\mathrm{t}_{\text {tabel }}\right)$; ${ }^{\mathrm{NS}}=$ Koefisien Korelasi tidak signidfikan ( $\mathrm{t}$ hitung $<\mathrm{t}$ tabel ); $\mathrm{r}$ y2.1 = Koefisien Korelasi parsial X2 dengan Y jika X1 dikontrol; $\mathrm{r}$ y2.3 = Koefisien Korelasi parsial X2 dengan Y jika X3 dikontrol; $r$ y2.13 = Koefisien Korelasi parsial X2 dengan Y jika X1 dan X3 dikontrol.

Hubungan antara tingkat kepercayaan diri (X3) dengan motivasi kerja (Y) hasil perhitungan : apabila dilakukan pengontrolan terhadap variabel (X1), maka di dapat $\mathrm{r}_{\mathrm{y} 3.1}=0,417$. Uji signifikansi dengan harga $\mathrm{t}_{\text {hitung }}$ sebesar 3,62 dan harga $\mathrm{t}_{\text {tabel }}$ sebesar 2,37 pada $\alpha=0,01$ adalah signifikan. Bila dilakukan pengontrolan terhadap (X2) didapat $\mathrm{r}_{\mathrm{y} 3 . .2}=$ 0,562. Uji signifikansi dengan uji t diperoleh harga $t$ hitung sebesar 5,35 dan harga $t$ tabel sebesar 1,66 pada $\alpha=0,05$, korelasi parsial menjadi tidak signifikan. Dan jika dilakukan pengontrolan terhadap variabel (X1) dan variabel (X3) secara bersama-sama diperoleh koefisien korelasi parsial sebesar $\mathrm{r}_{\text {y3.1 }} 2=0,392$ korelasi tidak signifikan. Hasil perhitungan korelasi parsial tersebut dapat disajikan seperti pada tabel sebagai berikut:

Tabel 8. Uji Sgnifikansi Koefisien Korelasi antara X3 dengan Y

\begin{tabular}{|c|c|c|c|c|c|}
\hline \multirow[t]{2}{*}{$\mathrm{n}$} & Koefisien & Koefisien & & \multicolumn{2}{|c|}{$\mathrm{t}_{\text {tabel }}$} \\
\hline & $\begin{array}{c}\text { Korelasi } \\
\mathrm{r}_{\mathrm{y} 3}\end{array}$ & $\begin{array}{l}\text { Determinasi } \\
\left(\mathrm{r}_{\mathrm{y} 3)^{2}}{ }^{2}\right.\end{array}$ & $\mathrm{t}_{\text {hitung }}$ & 0,05 & 0,01 \\
\hline 63 & 0,674 & 0,247 & $7,25^{* *}$ & 1,66 & 2,37 \\
\hline
\end{tabular}

Tabel 9. Uji Sgnifikansi Koefisien Korelasi parsial antara X3 dengan Y

\begin{tabular}{cccc}
\hline Koefisien Korelasi & & \multicolumn{2}{c}{$\mathrm{t}_{\text {tabel }}$} \\
\cline { 3 - 4 } Parsial & $\mathrm{t}_{\text {hitung }}$ & 0,05 & 0,01 \\
\hline $\mathrm{r}_{\mathrm{y} 3.1}=0,417$ & $3,62 *$ & 1,66 & 2,37 \\
$\mathrm{r}_{\mathrm{y} 3.2}=0,562$ & $5,35^{*}$ & 1,66 & 2,37 \\
$\mathrm{r}_{\mathrm{y} 3.12}=0,392$ & $3,32^{*}$ & 1,66 & 2,37 \\
\hline
\end{tabular}


Keterangan: $* *=$ Koefisien Korelasi sangat signifikan $\left(\mathrm{t}\right.$ hitung $\left.>\mathrm{t}_{\text {tabel }}\right)$; ${ }^{\mathrm{NS}}=$ Koefisien Korelasi tidak signidfikan ( $\mathrm{t}$ hitung $<\mathrm{t}_{\text {tabel }}$ ); $\mathrm{r}_{\mathrm{y} 3.1}=$ Koefisien Korelasi parsial X3 dengan $\mathrm{Y}$ jika X1 dikontrol; $\mathrm{r}_{\text {y3.2 }}=$ Koefisien Korelasi parsial X3 dengan Y jika X2 dikontrol; $r$ y3.12 = Koefisien Korelasi parsial X3 dengan Y jika X1 dan X2 dikontrol.

Hubungan antara ketahanan fisik mental spiritual dan kemampuan mengelola stres serta tingkat kepercayaan diri (X1X2X3) secara bersama-sama dengan motivasi kerja. Berdasar hasil perhitungan maka didapat kadar hubungan $r_{\text {y.123 }}=0,701$ dan koefisien determinasi sebesar $\mathrm{R}^{2}$ y.123 $=0,492$ atau 49,2 \% hal ini menunjukkan bahwa kontribusi ketiga variabel berbas terhadap motinasi kerja sebesar 49,2\% sedangkan sisanya ditentukan oleh variabel lain yang tidak dikaji dalam penelitian ini.

Hubungan antara ketahanan fisik mental spiritual (X1) dengan motivasi kerja (Y), apabila dilakukan pengontrolan terhadap variabel (X2)., Berdasar hasil perhitungan maka didapat kadar hubungan adalah signifikan, dan bila dilakukan pengontrolan terhadap (X3) korelasi parsial signifikan. Dan jika dilakukan pengontrolan terhadap variabel (X2) dan variabel (X3) secara bersama-sama diperoleh koefisien korelasi parsial tidak signifikan, maka dapat disimpulkan hubungan antara ketahanan fisik mental spiritual (X1) secara parsial dengan motivasi kerja (Y) signifikan., tetapi jika dilakukan pengontrolan terhadap variabel (X1) dan variabel kemampuan mengelola stres (X2) secara bersama-sama dengan variabel tingkat kepercayaan diri (X3) koefisien korelasi tidak signifikan hal ini berarti diperlukan pelatihan-pelatihan kepada pekerja front office dalam menjalankan tugas untuk meningkatkan kepercayaan diri.

Hubungan antara kemampuan mengelola stres (X2) dengan motivasi kerja (Y) hasil perhitungan : apabila dilakukan pengontrolan terhadap variabel (X1) adalah signifikan., tetapi bila dilakukan pengontrolan terhadap (X3) korelasi parsial menjadi tidak signifikan., dan jika dilakukan pengontrolan terhadap variabel (X1) dan variabel (X3) secara bersamasama diperoleh koefisien korelasi parsial tidak signifikan. Hal ini hasil analisis adalah konsisten dengan analisis pertama yaitu Hubungan antara ketahanan fisik mental spiritual (X1) dengan motivasi kerja (Y), apabila dilakukan pengontrolan terhadap variabel (X2)., maka diperlukan pelatihan-pelatihan kepada pekerja front office dalam menjalankan tugas untuk meningkatkan kepercayaan diri.

Hubungan antara tingkat kepercayaan diri (X3) dengan motivasi kerja (Y) hasil perhitungan : apabila dilakukan pengontrolan terhadap variabel (X1)., maka hasil di dapat adalah signifikan. Bila dilakukan pengontrolan terhadap (X2) didapat korelasi parsial menjadi tidak signifikan. Dan jika dilakukan pengontrolan terhadap variabel (X1) dan variabel (X2) secara bersama-sama diperoleh koefisien korelasi parsial tidak signifikan. hal ini semakin menunjukkan konsistensi hasil analisis., bahwa ketahanan fisik mental spiritual signifikan dengan kemampuan mengelola stres tetapi tidak signifikan dengan kepercayaan diri, maka sangat mendesak diperlukan pelatihan-pelatihan peningkatkan kepercayaan diri kepada para pekerja front office unbtuk mendukung dalam menjalankan tugas untuk. 
Hubungan antara ketahanan fisik mental spiritual dan kemampuan mengelola stres serta tingkat kepercayaan diri (X1X2X3) secara bersama-sama dengan motivasi kerja (Y). Berdasar hasil perhitungan maka didapat kadar hubungan $\mathrm{r}_{\text {y.123 }}=0,701$ dan koefisien determinasi sebesar $\mathrm{R}^{2}$ y.123 $=0,492$ atau 49,2 \% hal ini menunjukkan bahwa kontribusi ketiga variabel berbas terhadap motinasi kerja sebesar 49,2\% sedangkan sisanya 50,8\% ditentukan oleh variabel lain yang tidak dikaji dalam penelitian ini. Halini menujukkan bahwa hubungan ke tiga variabel bebvas secara secara bersama-sama mempunyai hubungan yang masih dikategorikan rendah 49,2\%, sehingga diidentifikasi varaiabelvariabel yang mempunyai hubungan yang signifikan dengan motivasi kerja, karena masih sebesar 50,8\% variabel-variabel bebas yang tidak masuk dalam kerangka penelitian.

\section{PENUTUP}

Simpulan. Pertama. Hubungan antara ketahanan fisik mental spiritual (X1) dengan motivasi kerja (Y), apabila dilakukan pengontrolan terhadap variabel (X2)., kadar hubungan adalah signifikan, tetapi bila dilakukan pengontrolan terhadap (X3) korelasi parsial signifikan. Dan jika dilakukan pengontrolan terhadap variabel (X2) dan variabel (X3) secara bersama-sama diperoleh koefisien korelasi parsial tidak signifikan, maka dapat disimpulkan hubungan antara ketahanan fisik mental spiritual (X1) secara parsial dengan motivasi kerja (Y) adalah signifikan. Berdasar hal di atas, maka hubungan antara ketahanan fisik mental spiritual dengan motivasi kerja adalah signifikan ( Hipotesis pertama terbukti ). Kedua. Hubungan antara kemampuan mengelola stres (X2) dengan motivasi kerja (Y) apabila dilakukan pengontrolan terhadap variabel (X1) adalah signifikan., tetapi bila dilakukan pengontrolan terhadap (X3) korelasi parsial menjadi tidak signifikan., dan jika dilakukan pengontrolan terhadap variabel (X1) dan variabel (X3) secara bersama-sama diperoleh koefisien korelasi parsial tidak signifikan, maka dapat disimpulkan hubungan antara kemampuan mengelola stres (X2) secara parsial dengan motivasi kerja (Y) adalah signifikan. Berdasar hal di atas, maka hubungan antara kemampuan mengelola stress dengan motivasi kerja adalah signifikan (Hipotesis ke dua terbukti). Ketiga. Hubungan antara tingkat kepercayaan diri (X3) dengan motivasi kerja (Y) hasil perhitungan : apabila dilakukan pengontrolan terhadap variabel (X1)., maka hasil di dapat adalah signifikan. Bila dilakukan pengontrolan terhadap (X2) didapat korelasi parsial menjadi tidak signifikan. Dan jika dilakukan pengontrolan terhadap variabel (X1) dan variabel (X2) secara bersama-sama diperoleh koefisien korelasi parsial tidak signifikan, maka dapat disimpulkan hubungan antara tingkat kepercayaan diri (X3) secara parsial dengan motivasi kerja (Y) adalah signifikan. Berdasar hal di atas, maka hubungan antara tingkat kepercayaan diri dengan motivasi kerja adalah signifikan. ( Hipotesis ke tiga terbukti ). Keempat. Hubungan antara ketahanan fisik mental spiritual dan kemampuan mengelola stres serta tingkat kepercayaan diri (X1X2X3) secara bersama-sama dengan motivasi kerja (Y). Berdasar hasil perhitungan maka didapat kadar hubungan $\mathrm{r}_{\mathrm{y} \cdot 123}=0,701$ dan koefisien determinasi sebesar $\mathrm{R}^{2}$ y.123 $=0,492$ atau 49,2 \% hal ini menunjukkan bahwa kontribusi ketiga variabel berbas terhadap motinasi kerja sebesar 49,2\% sedangkan sisanya $50,8 \%$ ditentukan oleh variabel lain yang tidak dikaji dalam penelitian ini. Hal ini menujukkan bahwa hubungan ke tiga variabel bebvas secara secara bersama-sama mempunyai hubungan yang masih dikategorikan rendah 49,2\%. Berdasar hal di atas, maka hubungan antara ketahanan fisik mental spiritual dan kemampuan mengelola stres serta 
tingkat kepercayaan diri secara bersama-sama dengan motivasi kerja adalah signifikan ( Hipotesis ke empat terbukti ).

Implikasi manajerial. Dari ke tiga variable tersebut ternyata tingkat kepercayaan diri (X3) merupakan variable yang sangat mendasar dalam memotivasi kerja. Dalam meningkatkan rasa percaya diri gejala yang cukup menentukan dan dapat diaplikasikan dalam usaha meningkatkan motivasi kerja. Kurangnya variabel-variabel bebas yang dipakai/masuk dalam model penelitian, karena jika di simak secara seksama hasil secara keseluruhan menunjukkan bahwa: hubungan antara ketahanan fisik mental spiritual dan kemampuan mengelola stres serta tingkat kepercayaan diri (X1X2X3) secara bersamasama dengan motivasi kerja $(\mathrm{Y})$ didapat kadar hubungan $\mathrm{r}_{\mathrm{y} .123}=0,701$ dan koefisien determinasi sebesar $\mathrm{R}^{2}$ y.123 $=0,492$ atau 49,2 \% Untuk itulah manajer harus memperhatikan dan menindaklanjuti karena ini menunjukkan bahwa kontribusi ketiga variabel berbas terhadap motinasi kerja hanya sebesar 49,2\%, maka diperlukan identifikasi variabel-variabel bebas yang lebih banyak untuk dapat semakin saksama yang berhubungan dengan motivasi kerja.

Saran. Untuk memperbaiki motivasi kerja, maka terdapat beberapa hal yang harus diperhatikan oleh perusahaan usaha jasa perhotelan didaerah kabupaten/kota Solo yaitu: Pertama. Perlu diprioritaskan untuk memberikan bentuk-bentuk pelatihan yang tepat guna meningkatkan kepercayaan diri kepada para pekerja front office dalam menjalankan tugas. Kedua. Untuk semakin memperbaiki Pola Hubungan antara kemampuan mengelola stres (X2), ketahanan fisik mental spiritual (X1) dengan motivasi kerja (Y) karena apabila dilakukan pengontrolan terhadap variabel ketahanan fisik mental spiritual (X1) hasilnya adalah signifikan. Ketiga. Untuk meningkatkan motivasi kerja para pekerja front office, maka usaha meningkatkan kepercayaan diri sangat mendesak diperlukan pelatihanpelatihan peningkatkan kepercayaan diri kepada para pekerja front office untuk mendukung dalam menjalankan tugasnya (antara lain: Public Speeking, writen comucation,Manajemen Stres), karena ketahanan fisik mental spiritual signifikan dengan kemampuan mengelola stres tetapi tidak signifikan dengan kepercayaan diri. Keempat. Untuk meningkatkan motivasi kepada para pekerja front office, pengusaha jasa perthotelan didaerah kabupaten/kota solo maupun para peneliti perlu secara cermat mengidentifikasi varaiabel-variabel yang mempunyai hubungan dengan motivasi kerja, , karena masih sebesar 50,8\% variabel-variabel bebas yang tidak masuk dalam kerangka penelitian ini.

Berdasarkan uraian seperti tersebut di atas maka saran secara umum pengusaha usaha jasa perhotelan didaerah kabupaten/kota Solo harus selalu berusaha memberikan kebebasan dalam mengatasi rintangan, kepercayaan memainkan peranan yang amat penting, di samping itu usaha peningkatan kemampuan bekerja yaitu dengan pendidikan dan latihan. Faktor kejujuran perlu ditanamkan. Kepercayaan diri akan menimbulkan keberanian untuk mencoba meningkatkan kretivitas \& produktivitas kerja.

Keterbatasan Penelitian. Kurang lengkapnya variabel-variabel bebas yang dipakai dalam model penelitian ini dan pada umumnya pengusaha jasa perthotelan didaerah kabupaten/kota solo dalam penempatan karyawan belum sesuai dengan keahlian/spesifikasi, hal ini terlihat bahwa walaupun Hubungan antara ketahanan fisik mental spiritual dan kemampuan mengelola stres serta tingkat kepercayaan diri secara bersama-sama mempunyai hubungan yang signifikan dengan motivasi kerja, namun secara persentase masih rendah. Hal ini dapat terlihat setiap perhitungan bahwa kepercayaan diri 
sebagai pengontrol terhadap variabel bebas (X1) atau variabel bebas (X2) hasilnya tidak signifikan.

\section{DAFTAR RUJUKAN}

Anthony, Robert N, John Deaden, Vijay Govindarajan, (1985) Management Control System, Seventh Edition, Homewood, Illinois: Richard D.Irwin Inc.

Anoraga. P (2009) Manajemen Bisnis. Jakarta: Rineka Cipta

Azwar, Saifuddin. (2003) Penyusunan Skala Psikologi. Yogyakarta. Pustaka Pelajar.

Colquitt, Lepine, Wesson. (2009) Organizational behaviour. McGrow Hill International Edition.

Donnely, R, Donnely Mel Gibson John Ivancevich (1997) Organizatioanal Behavior Structure Prosses. Michigan: Timer Higer Education Group.

Daft, Richard L., (2002) Manajemen, 2002, Edisi 4, Erlangga, Jakarta.

Davis, Keith. , (2002) Fundamental Organization Behavior, Diterjemahkan Agus Dharma, Jakarta: Erlangga.

Dharma, Surya. (2005) Manajemen Kinerja. Penerbit: Pustaka Pelajar

George dan Jones. (2005) Understanding and Managing Organizational behaviour 4 th edition. Pearson. Prentice Hall.

Hasibuan, malayu p. (2003) Manajemen sumber daya manusia. Edisis revisi. Jakarta: Bumi Aksara.

Hernowo dan M. Farid (2005) ”Pengaruh Motivasi dan Disiplin terhadap Kinerja Pegawai Badan Kepegawaian Daerah Kabupaten Wonogiri”.Tesis

Hadi Sutrisno, (2000) Seri program statistik versi 2000 Universitas Gadjah Mada, Yogyakarta.

Ghozali, Imam, (2008) Model Persamaan Struktural Konsep dan Aplikasi dengan Program Amos 16. 0, Badan Penerbit UNDIP, Semarang

Imam, Ghozali, (2009) Analisis Aplikasi Multivariate dengan Progam SPSS, Semarang: Universitas Diponegoro.

Kelly, George (1992) The Kognitif perpective in personality theory, dikutip langsung oleh Larry A Helle \& Daniel J. Zieger, Personality Theories - Basic Assumptions, Research and Application. New York: McGraw_Hill, Inc.

Kreitner dan Kinicki. (2008) Organizational behaviour 8 th edition. McGrow Hill International Edition.

Kuncoro, M. (2003) Metode Riset untuk Bisnis \& Ekonomi. Jakarta: Erlangga.

Marpaung, Happy, (1984) Himpunan Peraturan Pariwisata Indonesia, Bandung penerbit toris.

Mangkunegara, A. P. (2011) Manajemen Sumber Daya Manusia Perusahaan. Bandung: ROSDA.

Marwansyah. (2010) Manajemen Sumber Daya Manusia (Ed. 2). Bandung: Alfabeta

Mega Arum (2010) "Pengaruh Lingkungan Kerja Terhadap Kepuasan Kerja dan Kinerja Karyawan (Studi pada perum Jasa Tirta I Malang Bgaian Laboraturium Kualitas Air)"

Nelson, Davis, (2001) Moral Magazine, $\underline{\text { http://www.spiraldynamic. }}$ Com/magazine/editorials/ark.htm. 
Paul Hersey and Kenneth H Blanchard (1988) Management of Organizational Behavior Utilizing Human Resources, Singapore Prentice- Hall,Inc.

Purwanto dan Wayuddin (2007) "Pengaruh Faktor-Faktor Kepuasan Kerja Terhadap Kinerja Karyawan Pusat Pendidikan Komputer Akuntansi IMKA di Surakarta”

Raymond A, Noe., dkk. (2010) Manajemen Sumber Daya Manusia (mencapai keunggulan bersaing) Ed 6. Jakarta: Salemba Empat

Robbins, S. P, (2005) "Organizational Behavior Concept, Controversiest, Applications”, 6 Ed. Pretince Hall, Inc. Eaglewood, Cliff, New Jersey

Subekhi, Akhmad. , Jauhar, Mohammad. (2012) Pengantar Manajemen Sumber Daya Manusia (MSDM). Jakarta: Prestasi Pustaka

Sugiyono. (2004) Metode Penelitian Bisnis, Alfabeta, Bandung.

Suwarto F.X., (2015) "Pengaruh Budaya Organisasi dan Pengembangan Karier Terhadap Kepuasan Kerja Serta Dampaknya Terhadap Kinerja Karyawan, Publikasi Jurnal Nasional terakreditasi”, Jurnal Manajemen UNTAR , XIX (02):170-189, Juni/2015.

Theresia Sunarni, et al, (2007) "Pengaruh Stres Kerja Dan Motivasi Kerja Terhadap kinerja Karyawan Di Pt. Interbis Sejahtera Palembang” Jurnal Teknik Industri, 7 (2) Des 2007. 